\title{
Assessing Socioeconomic Impacts of Climate Change on US Forests, Wood- Product Markets, and Forest Recreation
}

LLOYD C. IRLAND, DARIUS ADAMS, RALPH ALIG, CARTER J. BETZ, CHI-CHUNG CHEN, MARK HUTCHINS, BRUCE A. MCCARL, KEN SKOG, AND BRENT L. SOHNGEN

\section{$\mathbf{S}$} cientists have suggested that future climate

change will significantly affect the distribution, condition,species composition, and productivity of forests (Aber et al. 2001, Dale et al. 2001, Hansen et al. 2001, McNulty and Aber 2001). These biological changes will set in motion complex regional changes in supplies of wood to sawmills and paper mills, producing effects on market prices. In turn, landowners and consumers will adapt in ways that cause further feedback effects on forests. For some time,social scientists have been assessing the manifold implications for social and economic welfare. In particular, they have been examining ways in which price responses to changing supplies cause timber growers, sawmills and pulpmills, producers, and consumers to adapt. This paper reviews this research, focusing on the forest benefits of timber production and outdoor recreation. Analyzing these sectors involves quite different methods and issues because wood products are primarily producer goods that reach consumers through a complex marketing chain, whereas forest-recreation experiences are directly consumed by visitors. As part of the national assessment of climate change, a socioeconomic team (the authors of this article) assembled existing data and conducted limited new analyses. In this short summary, many important topics must be left aside.

\author{
THE EFFECTS OF CLIMATE CHANGE ON \\ FORESTS WILL TRIGGER MARKET ADAPTA- \\ TIONS IN FOREST MANAGEMENT AND IN \\ WOOD-PRODUCTS INDUSTRIES AND MAY \\ WELL HAVE SIGNIFICANT EFFECTS ON \\ FOREST-BASED OUTDOOR RECREATION
}

In this paper we discuss the problems of projecting social and economic changes affecting forests and review recent efforts to assess the wood-market impacts of possible climate changes. To illustrate the range of conditions encountered in projecting socioeconomic change linked to forests, we consider two markedly different uses: forest products markets and forest recreation. In the case of forest products, we use an existing forest-sector model to arrive at new simulation results concerning the impacts of climate change. The impact of

Lloyd C. Irland (e-mail: irland@aol.com) is president of The Irland Group, Winthrop, ME 04364. Darius M. Adams is Professor of Forest Economics at Oregon State University, Corvallis, OR 97330. Ralph Alig is Research Forester at USDA Forest Service, Pacific Northwest Research Station, Forestry Sciences Lab, Corvallis, OR 97331. Carter J. Betz is Outdoor Recreation Planner at USDA Forest Service,Southern Research Station, Athens, GA 30602-2044. Chi-Chung Chen is Assistant Professor at National Chung Hsing University, Taichung, Taiwan. Bruce A. McCarl is Professor of Agricultural Economics at Texas A\&M University, College Station, TX 77843-2124. Mark Hutchins is Project Engineer at Sno-Engineering, Inc.,Hanover, NH 03755. Ken Skog is Project Leader at USDA Forest Service, Forest Products Laboratory, Timber Demand and Technology Assessment Research, Madison, WI 53706. Brent L. Sohngen is Associate Professor at Ohio State University, Agricultural,Environmental, and Development Economics, Columbus, OH 43210-1067. @ 2001 American Institute of Biological Sciences. 
climate change on recreation has received less attention;here we consider a case study of downhill skiing. Other important forest values were not treated explicitly in this research.Our primary emphasis is on methods and issues in the socioeconomic assessment process. Our efforts may be viewed as an exercise in human ecology, studying complex interactions between human societies and their forests. We close with suggestions for future research.

\section{Projecting social changes}

Climate change will affect forest growth, inventories, and harvest levels slowly, over many decades. The specific forest changes at a regional scale are highly uncertain. These biological changes will affect recreation, wood-product markets, and other forest benefits, all with differing lag times. Uncertainties concerning levels of population,incomes,spending patterns, per capita consumption of products, and international trade become increasingly severe as longer time periods are considered. Benchmark projections of population, for example,involve considerable uncertainty (Figure 1). Moreover, it is difficult to explicitly model how decisionmakers might incorporate expected changes in climate in their management decisions. Consequently, economic models to date have relied heavily on assumptions. They necessarily incorporate the assumptions employed in the underlying vegetation models, which typically do not explicitly incorporate forest management (e.g., pine planting in the South).

North America is the world's leading producer and consumer of wood products. The United States depends on Canada for 35\% of its softwood lumber and more than half of its newsprint. US exports of kraft paper, hardwood lumber, chips, logs, and other products are substantial. Modeling US wood-product markets, then, involves assumptions about future supplies, demands, and competitiveness among the major trading partners of the United States.

The current generation of models for assessing the economic effects of climate change, however, provides considerable insight into the likely magnitudes of social impacts and illustrates the possibilities for market-mediated responses to those impacts (Mendelsohn and Neumann 1999). Assessments of the impacts of climate change must link a series of models dealing with population and demand determinants, resource conditions, product markets, trade, and consumer and producer welfare. The modeling and data uncertainties at each stage of the analysis multiply in their effects on the results.

\section{Studies of wood-product market adaptat ion to ecological changes}

A considerable economic literature has developed, analyzing (1) adaptation in land management and in product markets and (2) the role of forest management in carbon (C) sequestration. Economic studies typically begin with steadystate, doubled-CO $\mathrm{CO}_{2}$ climate-change predictions from several climate models (general circulation models, or GCMs). Ecological models use these results to predict the steady-state eco- logical consequences. Economists develop scenarios of the ecological changes and introduce those effects into their economic models, which then simulate how markets are likely to respond. Because the GCMs and ecological models are spatially explicit, economic models can capture regional effects. Different US and world regions may gain or lose advantage in timber growing and wood production with climate change.

Past studies employ a variety of assumptions about the ecological effects of assumed future climate change (Table 1). Within the range of effects examined,however, one conclusion appears warranted: Adaptation in US timber and woodproduct markets will offset some of the potential negative effects of climate change. The wood products sector may even benefit from the changes in the sense that, under climate change, the net change in consumer plus producer economic benefits may be positive (Winnett 1998, Sohngen and Sedjo 1998, Sohngen and Mendelsohn 1998, Sohngen and Alig 2000).

Adaptat ion in land management. Binkley (1988) first explicitly linked the ecological effects of climate change with a timber model. He considered only changes in boreal forests and did not predict market effects in the United States. More recently, Joyce et al. (1995) linked the TEM biogeochemical cycle model (Melillo et al. 1993) to the TAMM/ NAPAP/ATLAS model to project how US timber markets adapt to changes in forest production (Table 1). Perez-Garcia et al. (1997) use the same ecological and climate models as Joyce et al. (1995) in a global analysis (Table 1). The authors trace the economic effects through to the wood-processing sector. US lumber and plywood production increases under all scenarios, while pulpwood production decreases under some scenarios. Overall, consumers and mill owners would gain welfare (profits for mill owners) during climate change, while landowners would lose welfare.

Sohngen and Mendelsohn (1998) provide results for 36 combinations of climate $\left(2 \times \mathrm{CO}_{2}\right)$, biogeochemical, and biogeographical changes in forests from VEMAP (Vegetation/Ecosystem Modeling and Analysis Project) members (1995; Table 1). They focus explicitly on adaptation in forestland management under the assumption that woodprocessing capital shifts to regions with economic advantages in timber growth. Forest area change is captured with either a dieback scenario (King and Neilson 1992) or a less dramatic regeneration scenario. Markets generally adapt to shortterm increases in mortality by reducing prices, salvaging dead and dying timber, and replanting new species that are favorably adapted to the new climate (Table 2). Salvage during dieback ranges from $50 \%$ to $75 \%$, depending on management intensity. Total benefits to producers plus consumers rise in all scenarios considered. Comparisons of carbon fluxes predicted by this model with those cited in earlier naturaladaptation studies by King and Neilson (1992) and Smith and Shugart (1993) suggest that market adaptation can reduce or reverse the potential forest carbon fluxes caused by climate change in the United States. 
Adaptat ion in product markets. Adaptations may include using alternative species in the manufacturing process, changing the nature or location of capital and machinery, changing reliance on imports or exports, or adopting new technologies. Previous studies implicitly capture substitution of end products in markets because they incorporate market relationships for timber and products. The models treat investments in capital over time differently. The model of Sohngen and Mendelsohn (1998) assumes that mill capital and machinery will adapt based on correct anticipation of the future impacts of climate change. Joyce et al. (1995) assume that capital and machinery will adjust more slowly. How rapidly mill investments respond to changes in supply and timber prices strongly affects endproduct price behavior.

New technologies,already emerging in response to market changes, represent another method of adapting to climate change. For example, new adhesives have led to new classes of wood panels and composites, which have displaced older

\section{U.S. population projections}

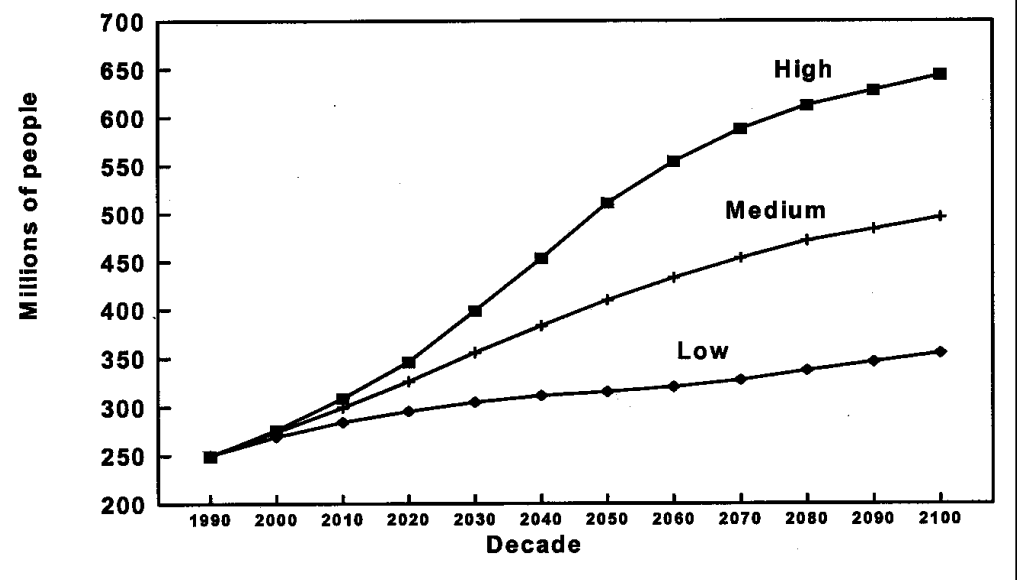

Figure 1. US populat ion projections, by decade, 1990-2100.

products. These new products often enable the industry to draw on more widely abundant species of trees that are also closer to end-use markets. Plastics have continued to displace traditional uses of wood, with innovations such as vinyl

\begin{tabular}{|c|c|c|c|c|}
\hline Attribute & $\begin{array}{c}\text { TAMM/NAPAP/ATLAS } \\
\text { (Used by } \\
\text { Joyce et al. } \\
\text { 1995) }\end{array}$ & $\begin{array}{c}\text { CGTM } \\
\text { (Used by } \\
\text { Perez-Garcia et al. } \\
\text { 1997) }\end{array}$ & $\begin{array}{c}\text { FASOM } \\
\text { (Used by } \\
\text { Burton et al. } \\
\text { 1998) }\end{array}$ & $\begin{array}{c}\text { VEMAP } \\
\text { (Used by Sohngen and } \\
\text { Mendelsohn } \\
\text { 1998) }\end{array}$ \\
\hline \multicolumn{5}{|l|}{ Timber model attribute } \\
\hline Theory & Spatial equilibrium & Spatial equilibrium & Dynamic optimization & Dynamic optimization \\
\hline Projection method & Static simulation & static simulation & Optimal control & Optimal control \\
\hline Harvest mechanism & N/A & $\mathrm{N} / \mathrm{A}$ & Oldest timber & Oldest timber \\
\hline Global scope & US-Canada & Global & US-Canada & Global \\
\hline Regions & $\sim 8$ & $\sim 40$ & $\sim 9$ & 4 \\
\hline Tracks regional trade & Yes & Yes & Yes & No \\
\hline Market structure & Multilevel & Multilevel & Log & Stumpage \\
\hline Capital adjustment & Adaptive & Adaptive & Rational & Rational \\
\hline Land management & Exogenous & Exogenous & Edogenous & Endogenous \\
\hline \multicolumn{5}{|c|}{ Climate and ecological change model attribute } \\
\hline Climate scenarios & 4 & 4 & None explicit & 2 \\
\hline Biogeochemical models & 1 model (TEM) & 1 model (TEM) & None explicit & $\begin{array}{l}3 \text { models (VEMAP } \\
\text { members 1995) }\end{array}$ \\
\hline Forest productivity & $\begin{array}{l}\text { Annual growth changes } \\
\text { linked to NPP }\end{array}$ & $\begin{array}{l}\text { Annual growth changes } \\
\text { linked to NPP }\end{array}$ & $\begin{array}{l}\text { Assumed changes in } \\
\text { annual growth }\end{array}$ & $\begin{array}{l}\text { Annual growth changes } \\
\text { linked to Vegetative } \\
\text { carbon }\end{array}$ \\
\hline Biogeographical models & None & None & None & $\begin{array}{l}3 \text { models (VEMAP } \\
\text { members 1995) }\end{array}$ \\
\hline Forest species migration & None & None & None & Dieback and regeneration \\
\hline Dynamic climate change & Linear & Linear & Compounded & Linear \\
\hline Years to doubling $\mathrm{CO}_{2}$ & 75 & 75 & 60 & 70 \\
\hline Years in model run & 50 & 50 & 60 & 150 \\
\hline
\end{tabular}


Table 2. Four studies of the economic ffects of climate change scenarios on timber markets.

\begin{tabular}{|c|c|c|c|c|}
\hline Study & Joyce et al. (1995) & Perez-Garcia (1997) & Burton et al. (1998) & $\begin{array}{c}\text { Sohngen and } \\
\text { Mendelsohn (1998) }\end{array}$ \\
\hline Productivity & Generally increases & Generally increases & Increases or decreases & Increases or decreases \\
\hline Forest area & No change & No change & No change & Long-term increase \\
\hline Inventories & Increase & Increase & Increases or decreases & Long-term increase \\
\hline \multicolumn{5}{|l|}{ Timber prices } \\
\hline compared with baseline & Lower & Lower & Increase or decrease & Lower \\
\hline Market welfare & Not given & Increased & Increased or decreased & Increased \\
\hline
\end{tabular}

siding, plastic decking, and plastic and wood fiber composites. Increased recycling of paper and pallets has already dampened timber demand. New technologies have also helped mills produce more product value from a given tree; as this trend continues, the forest-based economy will be more resilient in the event that one of the future dieback scenarios transpires.

The studies described above focus on the United States.Effects on Canada's forest, a major source of US wood products, have also been reviewed (Van Kooten and Arthur 1989, Van Kooten 1995). Current research considers primarily the oneway impacts of a changing climate on forested ecosystems and consequently on the economy. A truly integrated analysis would fully incorporate feedbacks among the ecological system, insects, diseases and invasive plants, the economic system,carbon flux, and climate (see, for example, Goldewijk et al.1994). One such feedback is the role of forests and wood products in carbon storage.

Using forests to store carbon. A number of authors have suggested that forests could be used to increase the quantity of carbon stored in terrestrial ecosystems (Sedjo 1989, Winjum et al. 1998, Joyce and Birdsey 2000; for recent reviews,see Sedjo et al. 1997, Irland and Cline 1998). Many strategies have been examined (Adams et al. 1993,1999, Alig et al. 1997, Birdsey et al. 1999, Parks and Hardie 1995, Stavins 1999). Among these strategies are the following:

- setting aside existing forests from harvest, and controlling wildfires

- increasing carbon buildup in forests by converting marginal agricultural land to forests (carbon plantations, forest-product plantations, or joint-product plantations)

- enhancing forest management

- substituting wood products for more energy-intensive products (Skog et al. 1996)

- planting trees in urban regions to moderate urban climates

A substantial pool of carbon resides in forest products in use, as in houses. Heath et al. (1996) estimate that carbon stored in products harvested since 1900 equals 3.7 Pg carbon; Skog and Nicholson (1998) suggest that this amount is closer to 2.7 Pg. Estimates of net annual accumulation of carbon in wood products and landfills in the early 1990s ranged from $37 \mathrm{Tg}$ per year (Heath et al. 1996) to $61 \mathrm{Tg}$ per year (Skog and Nicholson 1998). Estimates by Plantinga and Birdsey (1993) and Skog and Nicholson (1998) suggest that annual storage in products and landfills will grow to approximately $70 \mathrm{Tg}$ per year by 2040 . Approximately $29 \%$ of paper is currently recycled by domestic mills. The USDA Forest Service estimates that this share may rise to $45 \%$ by the year 2040 (Haynes et al. 1995). Increasing the recycling rate to $60 \%$ by the year 2040 could reduce carbon emissions in the paper industry by $36 \mathrm{Tg}$ carbon per year and increase carbon storage in forested ecosystems by 8-14 Tg per year by lowering timber harvests (Skog et al. 1996). These amounts may not be large relative to total US emissions (1367 TG per year in 1990), but they are large relative to other options for $\mathrm{C}$ mitigation. Analysis worldwide has been conducted by Winjum et al. (1998).

Although considerable attention has been given to carbon storage issues (Watson et al. 2000), there has been no comprehensive social-impact assessment measuring consumer, producer, and environmental benefits. The future role of wood biomass as an energy source depends on oil prices and public policies and was not evaluated in the models reviewed here.

\section{Assessment simulation results: FASOM}

A study of the effects of global climate change on forestry should be based on accepted future scenarios for forest yield, but definitive scenarios have not yet emerged. Therefore, we analyzed four forest-growth scenarios based on paired applications of two global climate models and two ecologicalprocess models (EPMs). We estimated how baseline forest growth will change because of climate change. To assess the forest-yield scenarios, we used the FASOM model, as documented in Adams et al. (1997), Alig et al. (1998), Sohngen and Alig (2000), and Joyce and Birdsey (2000). Given a climatechange scenario, the FASOM model projects forest- and agricultural-sector production, consumption, prices, and economic welfare. To deal with competition for land, FASOM incorporates both sectors. FASOM is a multiperiod,nonlinear, price-endogenous, mathematical-programming economic model that provides 120 -year projections. Values of nonwood or noncommodity attributes of the forest are not considered. Products comprise fuelwood, sawtimber, and pulpwood. On the forest side, FASOM simulates 
- changes in timber inventory on private land

- manufacturers' adjustments in timber-product production

- consumers' adjustments in consumption

- forest landowners' conversion of forest to (or from) agriculture

- landowners' adjustment of forest management intensity and rotation age

Harvest on public lands and the net import of wood and wood products from Canada are taken as exogenous. In this analysis, Canadian imports were adjusted by the average percentage change in harvest observed in comparable regions on private lands in the United States to reflect the impacts of climate change. The impacts of climate on forest productivity (see Aber et al. 2001) were simulated using two biogeochemical models (EPMs): TEM (Melillo et al. 1993, McGuire et al. 1992) and CENTURY (Parton et al. 1987,1993). Possible effects of climate change on insects, diseases, invasive species, or fire regimes were not considered (Dale et al. 2001).

The four scenarios represent combinations of the two GCMs and two EPMs:

- Hadley-TEM (climate change from the Hadley GCM, changes in forest growth rate from the TEM EPM)

- Hadley-CENTURY (climate change from the Hadley GCM, changes in forest growth rate from the CENTURY EPM)

- CCC-TEM (climate change from the Canadian GCM, changes in forest growth rate from the TEM EPM)

- CCC-CENTURY (climate change from the Canadian GCM, changes in forest growth rate from the CENTURY EPM)

In contrast to the equilibrium climate scenarios used in earlier forest sector analyses (Joyce et al. 1995, Sohngen and Mendelsohn 1998), transient climate scenarios were used for this assessment. The climate under increased carbon dioxide was simulated annually from 1895 to 2100 ; the EPM models projected vegetation carbon annually over this period. Forest floor and soil pools were not simulated. For each grid cell, we computed the annual change in vegetation carbon for each model projection, converted these changes to a 10-year moving average, and used these changes to influence timber yields in FASOM. The ecosystem classification for each grid cell (VEMAP members 1995) was mapped to the major forest type (e.g., Joyce et al. 1995). The 10-year moving average changes in vegetation carbon were then averaged spatially across all grid cells for each forest type.

Changes in vegetation carbon varied for each region because of the regional climate and the changes in climate projected by the Hadley and Canadian models. For example, in the Northeast, the oak-hickory type has the largest change in annual growth rate-an increase of about $0.3 \%$ by 2100 (Figure 2). These changes in vegetation carbon by forest type are mapped into hardwood and softwood forest types and are used to change timber growth for the nine regions modeled in FASOM (see Adams et al. 1996, Alig et al. 1997, Mills et al. 2000).

Timber growth increases under all four cases in most regions for most decades. Growth increases over 10-year periods are relatively small. For most scenarios,species, and regions, decadal increases are from $1 \%$ to $3 \%$ of the prevailing growth rate. The most significant declines are for softwoods and hardwoods in the southeast and south-central regions for 2010-2040 for the Canadian-Century case. But growth rates are higher for all cases, regions, and species in later decades (Figure 2).

The results suggest that the assumed climate change scenarios, as indicated by these four cases, would be generally beneficial for the timber-products sector over the 120-year projection. This result is consistent with findings for the forthcoming agricultural sector of the national assessment. Increased forest growth translates into higher forest production, as represented by log harvest levels in most cases. By 2100, inventories are slightly higher for the climate-change scenarios compared with the base case (Table 3, Figure 3). Increased forest growth leads to increased log supply and hence to reductions in log prices that, in turn, decrease producers' welfare (profits) in the forest sector. At the same time,lower forest-

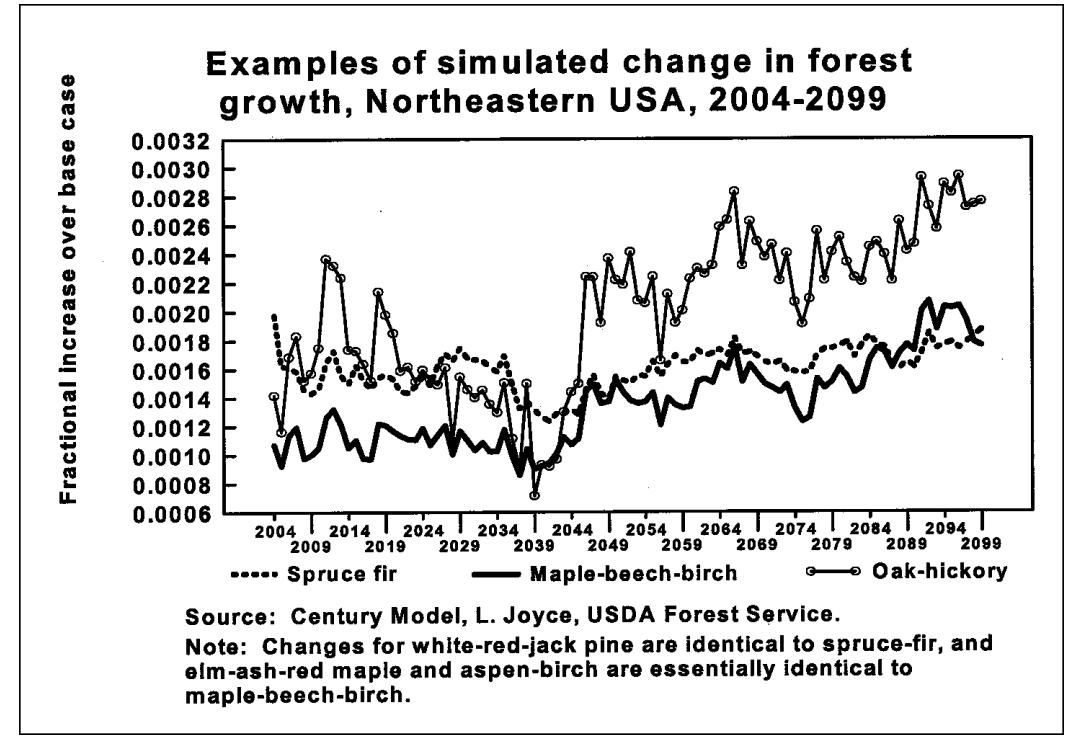

Figure 2. Example of simulated changes in forest growth, Northeast and entire United States, 2004-2009 (fractional increase over base case). 


\begin{tabular}{|c|c|c|c|c|}
\hline & \multicolumn{4}{|c|}{$\begin{array}{l}\text { Percentage change from } \\
\text { base-case projection }\end{array}$} \\
\hline & Had-T & Had-VM & Can-T & Can-VMAP \\
\hline \multicolumn{5}{|l|}{ Welfare (net present value) } \\
\hline Forest sector, 2000-2120 & 0.2 & 0.1 & 0.1 & 0.0 \\
\hline $\begin{array}{l}\text { Combined agriculture and } \\
\text { forest sectors,2000-2120 }\end{array}$ & 0.7 & 0.7 & 0.4 & 0.4 \\
\hline \multicolumn{5}{|l|}{ Forest price } \\
\hline PULPSW, avg 2000-2010 & -0.6 & -0.6 & -0.6 & -0.6 \\
\hline PULPSW, avg 2020-2050 & 3.1 & 3.1 & 3.8 & 3.8 \\
\hline SAWTSW, avg 2000-2010 & -0.4 & -0.4 & 0.0 & 0.0 \\
\hline SAWTSW, avg 2020-2050 & -6.4 & -5.3 & -5.3 & -3.7 \\
\hline \multicolumn{5}{|l|}{ Forest production (harvest) } \\
\hline PULPSW, avg 2000-2010 & 0.2 & 0.2 & 0.1 & -0.0 \\
\hline PULPSW, avg 2020-2050 & -3.1 & -3.0 & -3.3 & -3.1 \\
\hline SAWTSW, avg 2000-2010 & 0.5 & 0.4 & 0.2 & 0.0 \\
\hline SAWTSW, avg 2020-2050 & 1.4 & 0.6 & 0.8 & 0.4 \\
\hline \multicolumn{5}{|l|}{ Timber inventory } \\
\hline \multicolumn{5}{|l|}{ North,ALLWOOD } \\
\hline 2000-2010 & 0.1 & 0.2 & -0.1 & -0.0 \\
\hline $2020-2050$ & -1.3 & 0.2 & -0.1 & -0.0 \\
\hline \multicolumn{5}{|l|}{ South,ALLWOOD } \\
\hline 2000-2010 & 0.1 & 0.1 & -0.1 & -0.0 \\
\hline $2020-2050$ & 0.1 & 0.1 & -0.1 & -0.0 \\
\hline \multicolumn{5}{|l|}{ Land transfers, nationwide ${ }^{a}$} \\
\hline FORCROP, 2000-2010 & 3.1 & -0.1 & 3.1 & -0.6 \\
\hline FORCROP, 2020-2050 & -21.5 & -12.4 & -22.1 & -11.1 \\
\hline FORPAST, 2000-2010 & -0.4 & -1.4 & -12.3 & -12.3 \\
\hline FORPAST, 2020-2050 & -18.9 & -16.1 & 24.6 & 32.1 \\
\hline CROPFOR,2000-2010 & -100.0 & -93.0 & 115.3 & 159.9 \\
\hline CROPFOR, 2020-2050 & -100.0 & -100.0 & -82.9 & -93.6 \\
\hline PASTFOR,2000-2010 & 21.9 & 20.6 & 18.4 & 18.4 \\
\hline PASTFOR,2020-2050 & -89.1 & 98.5 & -8.9 & 76.7 \\
\hline
\end{tabular}

Note: Only softwoods reported separately, and only North and South illustrate regional projections. PULPSW, softwood pulpwood; SAWTSW, softwood sawtimber; FORCROP, forestland changed to cropland; CROPFOR, cropland changed to forest; PASTFOR, pasture changed to forest; FORPAST, forest changed to pasture.

a. Some of the changes here are very large, because the base case values are small. larger or smaller than the base case, depending on the scenario (Figure 3). In the longer term, aggregate inventories are lower than the base case in all scenarios. Across all regions and scenarios, cumulative hardwood output over the full projection period is higher; softwood production increases only in the Hadley GCM cases. In the North,cumulative output declines for all species in both Canadian GCM cases and in the Hadley-TEM case. In the South, in contrast,output increases in all cases and for both hardwoods and softwoods.

Compared with the base case, forest-product prices would generally be lower under the climatechange scenarios (Table 3), except for softwood pulpwood in the long term. Although overall wood production is projected to increase, the proportion of sawtimber (combining both softwoods and hardwoods) is somewhat larger with climate change in all scenarios,species, and regions. This shift in product mix reflects the impacts of accelerated growth on rotation age, which is lengthened in the long term for all regions and species. With longer rotations come larger volumes of sawtimber relative to pulpwood.

The effects of global climate change on forest growth based on the combined GCM-EPM scenarios have a generally positive impact on aggregate economic welfare. The projected aggregate market welfare impacts (consumers' savings plus producers' profits) from the climate-change scenarios are generally not large compared with the baseline, ranging from $+0.05 \%$ to $+0.18 \%$ in the forest sector and from $+0.37 \%$ to $+0.74 \%$ in the combined agriculture and forest markets. Yield increases and price reductions induced by climate change were found to benefit consumers but not producers. Thus, the aggregate welfare effects mask the distributional shifts between producers and consumers.

product prices (compared to baseline) mean that consumers generally benefit (Table 3). This pattern of distributional impacts on forestry producers and consumers is also consistent with results in the agricultural sector. The projected net effect on the economic welfare (producer profits plus consumer savings) of participants in both timber and agricultural markets is positive (Figure 4).

Land-use changes between forestry and agricultural uses are an important avenue of adjustment to climate-induced shifts in production. Yields generally increase in both the forest and agricultural sectors in all four scenarios, although the pattern between sectors varies substantially. In the Canadian scenarios, these shifts are relatively more favorable for forestry profits compared with agriculture, while the opposite is true in the Hadley scenarios.

Although total forest production generally increases because of climate changes under the four scenarios, regional and species differences are evident over time.Output and inventory changes are also poorly correlated. In both the North and South, total forest inventories in the near term are variously

\section{Effects on forest recreation}

Recreation is an important use of forest land. Leisure-time use of forests for outdoor recreation represents a direct interaction of people with the environment. Recreation is an extremely broad and diverse social phenomenon with each activity having its own environmental requirements, so it is difficult to generalize about climate change effects (Cordell et al.1999, Wall 1998). We reviewed existing information,seeking ideas on how forest-related recreation might be affected by climate change.Only limited understanding about potential climatic influences on outdoor recreation has emerged,and much of that is more accurately described as informed opinion than as science. Much of the work has appeared since the mid-1990s. For example, a 1992 National Academy of Sciences report devoted only about two pages (out of 900) to outdoor recreation (NAS 1992).

Seasonality is a major attribute of most tourist destinations. It affects both the types of recreational activities that occur in 


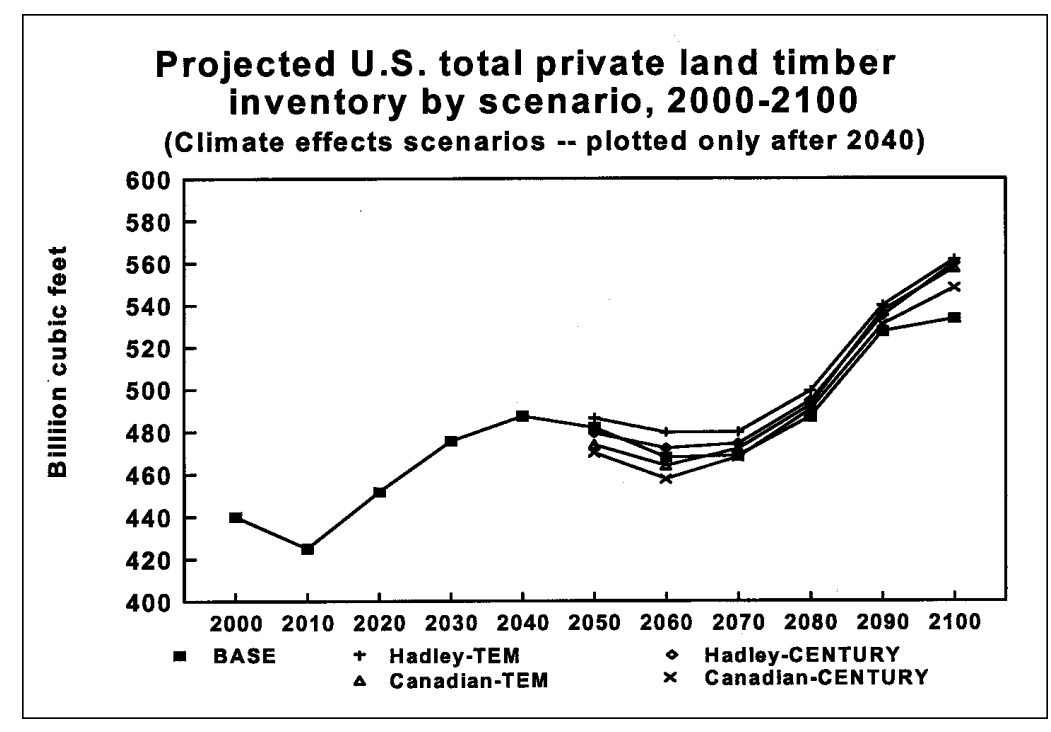

Figure 3. Projected US total private inventory by scenario, 2000-2100 (million cu. ft.).

a region and the amount of recreation that takes place. That is, individuals who live in one place and demand the attributes of a certain season are willing to travel to other places that supply those seasonal attributes. Classic examples are beaches and ski resorts.

Climate effects may be direct or indirect. Direct effects can be simply described as those straightforward effects on participants' desired demand for outdoor recreation due to either increased temperatures or changes in precipitation (Loomis and Crespi 1999). The best example of a direct effect is the extension, because of temperature increases, of the recreation season for a number of activities, especially water sports and beach-oriented recreation. Indirect effects, on the other hand, are those impacts arising through changes in the quantity and quality of natural resources used for outdoor recreation (Loomis and Crespi 1999). A good example is the potential change in reservoir levels due to increased evapotranspiration or changing precipitation. Lake levels are a good indicator of boating quality, so climate change has the potential to indirectly cause shifts in recreation visits because of its effects on water volumes.

Climatic conditions are an essential part of the forest recreational experience. For some activities, climate is the most critical aspect of the setting. Increased temperatures will produce a positive direct effect for any summer activity that would benefit from an extended season. Beach recreation,swimming, and boating, often pursued in forest settings, are some obvious beneficiaries. Negative effects may also arise, such as greater beach erosion (Yohe et al. 1999). Furthermore, higher temperatures and extended seasons in more temperate regions may actually reduce the demand for more tropical environments, such as
Florida beaches. The warming of waters may increase fish productivity for some species while causing declines or loss of other significant species (Schaake 1989, Shaw 1996, Bailey and Kerr-Upal 1997, Duk 1997, IISD 1997).

Sustaining coldwater fisheries is a key issue. There is little doubt that increased temperatures will significantly reduce available trout habitat and populations (Ahn 1997). Brook trout habitat, in particular, is likely to become increasingly limited and fragmented. A study by the US Environmental Protection Agency estimated changes in consumer benefits of recreational anglers from changing water temperatures (Michaels et al. 1995). Warmer temperatures resulted in a net loss in user benefits.

In mountainous landscapes (such as the Great Smoky Mountains National Park), where scenery and sightseeing are prominent attractions, warmer lowland temperatures will tend to attract more people to the relatively cooler higher elevations. Yet climate change could affect haze and could diminish the vividness of fall foliage and color displays (Bloomfield and Hamburg 1997).

Two recent statistical studies attempted to define the climate sensitivity of recreation visits on a national basis (Loomis and Crespi 1999, Mendelsohn and Markowski 1999). They estimated current aggregate days of activity and the economic value to visitors, and they projected these variables to 2060 (Table 4). The results suggest losses in consumer benefit for some activities and gains for others. Nonetheless, the analysis of the recreation effects of climate change is in its infancy. Clearly many forms of adaptation can accompany climate changes, though they may impose higher costs. The importance of recreation as a factor in the quality of life, its economic

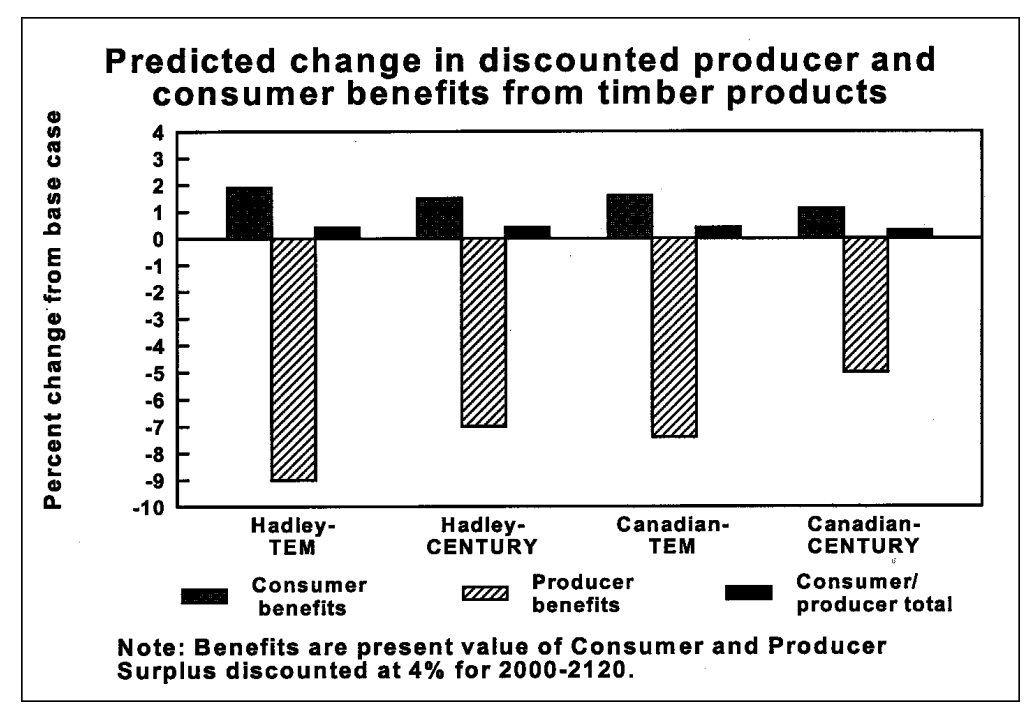

Figure 4. Potential change in discounted producer and consumer benefits from timber products (percentage change from base case). 


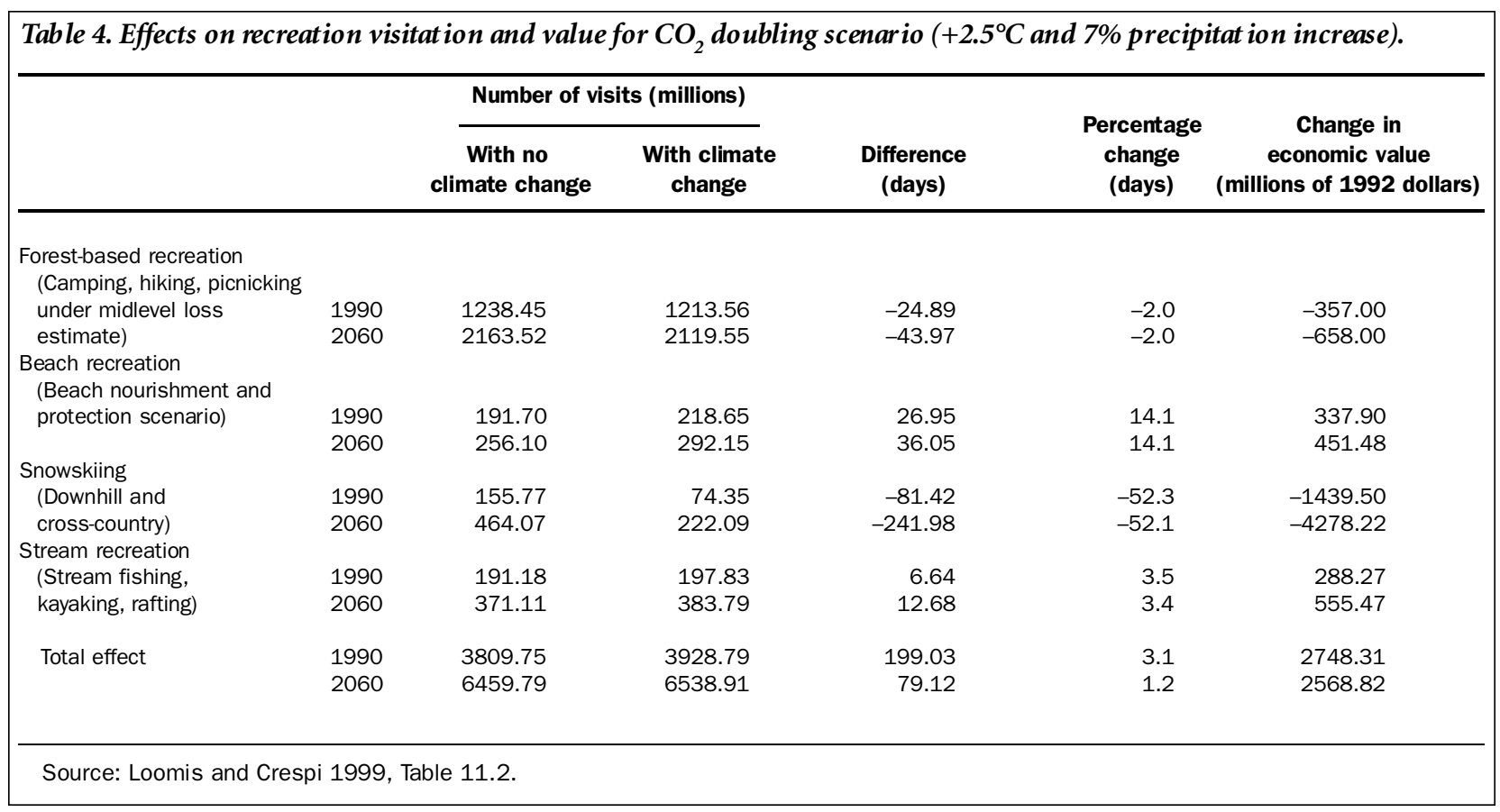

impact, its obvious climate sensitivities, and the many local and regional variations argue for a major increase in research on this topic.

\section{Possible effects of climate change on the ski industry}

Skiing is an important use of forested mountain landscapes and a key concern of land-managing agencies. It displays superficially straightforward links to climate regimes. The first ski areas in the United States were constructed during the 1930s. Thereafter, skiing's popularity soared, with the number of ski areas peaking during the 1960s and 1970s. Today there are considerably fewer ski areas (521 at the end of the 1998 ski season), and the number continues to decline. Successful ski areas must now provide high-speed lifts, overnight accommodations, modern snowmaking and grooming equipment, and other amenities.

Natural snowfall at western resorts is more dependable than at the eastern resorts. Snowfall in many westerly areas often exceeds that needed for acceptable skiing conditions. Thus, climatic variability is less important in the west. Nevertheless,many western resorts suffered a disastrous ski seasons in 1976 and 1977 because of the lack of natural snow. In addition, the ability to open early in the season is vital industrywide, and early-season snowfall is not dependable. Thus, machine-made snow plays an important role for ski areas and skiers throughout the country.

Three primary factors influence the ability of a ski area to make snow. Temperature and water availability are directly related to climate; energy is at least indirectly related. Most snowmakers do not begin operations until temperatures are below $-2^{\circ} \mathrm{C}$ and are expected to remain below $-2^{\circ} \mathrm{C}$ for at least four hours. Snowmaking efficiency is inversely related to temperature, so the cost of making an acre-foot of snow at $-12^{\circ} \mathrm{C}$ is cheaper by a factor of 5 than at $-2^{\circ} \mathrm{C}$. Energy requirements are high. For example, at Maine's Sunday River, annual electricity usage is approximately 26 million kilowatt-hours, most of which is for snowmaking (Hoffman 1998). This translates to nearly $\$ 2$ million per year just for electricity. Electricity costs for early-season snowmaking can be as much as $\$ 700$ per acre-foot of snow, while midwinter snowmaking can cost $\$ 25$ per acre-foot. A large resort can easily spend more than $\$ 100,000$ per night making early-season snow.

A higher average temperature in winter would have several effects. First, the number of hours that temperatures would exceed $-2^{\circ} \mathrm{C}$ would increase. This would increase the amount of snow melting, increase the number of rain events, and decrease the "window" for snowmaking while increasing the need for machine-made snow. Ski areas that typically have an excess of cold weather would adapt by increasing the capacity of their snowmaking systems (i.e., making more snow in a shorter period of time). Costs to skiers could rise to cover the increased costs. In areas where winter temperatures are already marginal (the mid-Atlantic region and southern Appalachians),some ski areas would probably be forced to close.

On the one hand, warmer temperatures and more rain events would most likely increase water availability. Although more water would be needed, greater availability could mean no net impact. In addition, people tend to stay home during periods of extreme cold, regardless of how good the skiing is. If the number of extremely cold days were reduced, skier visitation would probably increase. Therefore, the impacts of 
increased winter temperatures on the US ski industry remain speculative at best. For some areas, the impact could be disastrous. For others, it could result in no net impact. And for still others,warmer winter daytime temperatures or lower frequencies of extreme cold conditions could be beneficial.On the other hand, increased frequency of prolonged "thaws" would be damaging. Changes in winter precipitation have equally ambiguous impacts. If increased precipitation takes the form of snow, an area will need less machine-made snow. If it takes the form of rain,snowmaking needs will increase.

In summary, potential impacts of climate change on the ski industry remain uncertain (Table 5), because its links to the climate regime are complex. Although it seems likely that ski areas operating in marginal climates could be seriously affected, the effect on ski areas in colder regions is less clear. Snowmaking is a key adaptive mechanism. Actual impacts will be determined by the extent of climate-regime changes in specific regions and the details of how those changes manifest themselves. Averages may mean little. Lengthened summer seasons will not offset loss of skiing visits for marginal resorts. Results of aggregated statistical analyses suggesting dramatic losses to ski visitation need further validation by regional- and industry-level analysis. Key climate factors, adaptation options, and socioeconomic impacts would of course be different for other forms of forest recreation.

\section{Areas for future research}

Our review suggests many fertile fields for further socioeconomic research on the impacts of and adaptation to climate change:

- Evaluate how forest benefits other than timber and recreation (Swanson and Loomis 1996) are affected.
- Evaluate distributional outcomes (how regions and population subgroups are affected) of projected resource changes, price changes, and market adjustments.

- Evaluate recreation effects in greater detail,especially to understand market adaptations for regions and individual activities.

- Validate and update behavioral relations (such as supply and demand equations) depicting market adaptation in wood-product markets, outdoor recreation, and land-use change.

- Evaluate how global climate change will influence US forest-product trade.

- Evaluate the relative role of population and demand uncertainties compared with projected climatechange effects.

- Evaluate how quickly capital investments in timber growing and manufacturing may adapt to future regional changes in forest resources.

- Incorporate predicted investment and forestmanagement adaptations into new generations of vegetation models,including the results of coping practices, and richer scenarios for predicting the effects of insects, diseases, and invasive plants.

- Conduct a detailed analysis of the cost and effectiveness of suggested strategies for dealing with climate change effects on forests.

\begin{tabular}{|c|c|c|}
\hline $\begin{array}{l}\text { Climate parameter } \\
\text { of change }\end{array}$ & Physical impact of change & $\begin{array}{l}\text { Relative impact on } \\
\text { the ski industry }\end{array}$ \\
\hline Higher winter temperature & $\begin{array}{l}\text { Greater need for snow, either natural or } \\
\text { machine-made, due to increased melting } \\
\text { Reduced snowmaking opportunity } \\
\text { More water available to snowmaking due to } \\
\text { higher stream flow } \\
\text { Less need for and reliance on snowmaking } \\
\text { Storage ponds due to higher stream flow } \\
\text { Increase in skier visitation at resorts } \\
\text { Cheaper electricity }\end{array}$ & $\begin{array}{l}\text { Negative } \\
\text { Negative } \\
\text { Positive } \\
\text { Positive } \\
\text { Positive } \\
\text { Positive }\end{array}$ \\
\hline \multicolumn{3}{|l|}{ Greater winter precipitation } \\
\hline 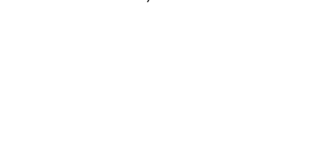 & $\begin{array}{l}\text { More water available for snowmaking due to } \\
\text { higher stream flow } \\
\text { Reduction in skier visitation at resorts } \\
\text { Need for and reliance on snowmaking } \\
\text { storage ponds-change undefined }\end{array}$ & $\begin{array}{l}\text { Positive } \\
\text { Negative } \\
?\end{array}$ \\
\hline More snow, less rain & $\begin{array}{l}\text { Less need for snowmaking } \\
\text { Less water available for snowmaking due to } \\
\text { lower stream flow } \\
\text { Potential reduction in skier visitation at } \\
\text { resorts if snowfall events are more frequent } \\
\text { Need for and reliance on snowmaking } \\
\text { storage ponds-change undefined }\end{array}$ & $\begin{array}{l}\text { Positive } \\
\text { Negative } \\
\text { Negative } \\
\text { ? }\end{array}$ \\
\hline
\end{tabular}




\section{Conclusion}

Assessing socioeconomic implications of climate change in the forest sector is a daunting task. Because timber and recreation markets function on a regional basis, evaluating change requires estimates of change in regional climates, which are still quite uncertain. Moreover, how vegetation and water resources will respond over time to a changing climate is uncertain. Commercial forests are modified at rates of $2 \%$ to $4 \%$ of area per year by timber harvesting, and planting is locally important. Also, considerable effort has been expended to understand carbon storage in forests and in wood products and options for using woody biomass for energy. Incorporating such human influences in models is critical. Over century-long time spans, national and regional populations,incomes, and demand for wood products will change, with a wide range of uncertainty. Climate-change effects seem likely to be small by comparison. Finally, international trade is important for many forest products and for recreation, and could well be affected by climate changes.

For outdoor recreation, which is a major forest use, formal modeling of climate-change effects has barely begun. Nonetheless, existing information suggests many possible effects. The example of ski areas illustrates the complexity of climateregime effects and illustrates the key adaptation of snowmaking as a coping strategy.

Current socioeconomic modeling capabilities can be viewed as first-generation tools useful for understanding problem structure and for analyzing improved vegetation forecasts as they are developed.Economic models generally predict that, under climate change, total US forest inventories will increase, timber harvests will increase, and product prices will decrease relative to an assumed stable climate. Although overall market welfare tends to increase, some models predict that consumers gain from climate change while landowners in some regions lose. Such distributional impacts can be analyzed further with these tools. Changes in prices can mitigate many of the most dramatic consequences of climate change in product markets by signaling producers and consumers to change behavior. Market adaptation involves a wide range of activities,including replanting forests that have died back,shifting harvests from one region or species to another, changing land uses, and developing new technologies. This emphasis on the many pathways for potential adaptations is a more important result than the particular numerical estimates, which will be revised with improved information.

Research to date has shown the importance of adaptive mechanisms in markets responding to climate-change impacts. However, any temptation to rely on current numerical estimates of socioeconomic impacts in making policy decisions should be resisted. In summarizing the current state of socioeconomic assessment for policymakers, overconfidence and oversimplification must be avoided. As current models are improved, they will become increasingly powerful tools for policy simulations and for providing a deeper understanding of the biological and social interactions shaping forests. Furthermore, the role to be played by economic in- formation in making policies about long-term environmental change remains much in debate (Portney 1999).

Economics invariably moves from analyzing economic processes and measuring price and income changes to suggesting which outcome or policy is most desirable. Some people might not consider the complete loss of alpine ecosystems in the United States a positive development. Learning that "the aggregate of consumer and producer surplus of wood products will be higher"may not change their view. It may be possible to derive an "existence value" for the alpine ecosystem using economic methods (Swanson and Loomis 1996). Finding a common metric for effects on lumber markets and effects on alpine meadows, however, will remain elusive.

\section{Acknowledgments}

Irland assembled this article from coauthor contributions: Adams, Alig, Chen, and McCarl developed the FASOM model and conducted new runs for this assessment; Betz reviewed literature on forest recreation; Hutchins prepared the case on the ski industry; Skog worked on carbon sequestration and assisted in drafting this summary; and Sohngen reviewed literature for this paper. The authors would like to acknowledge helpful aid from Virginia Dale, John Aber, Linda Joyce, and anonymous referees.

\section{References cited}

Aber J, Neilson RP, McNulty S, Lenihan JM, Bachelet D, Drapek RJ. 2001. Forest processes and global environmental change: Predicting the effects of individual and multiple stressors. BioScience 51: 735-751.

Adams DM, Alig RJ, McCarl BA, Callaway JM, Winnett SM. 1996. The Forest and Agricultural Sector Optimization Model: Model Structure and Applications. Portland (OR): USDA Forest Service. Research Paper PNW-RP-495.

-1999. Minimum cost strategies of sequestering carbon in forests.Land Economics 75: 424-433.

Adams RM, Adams DM, Callaway JM, Chang C-C, McCarl BA.1993. Sequestering carbon on agricultural land: Social cost and impacts on timber markets. Contemporary Policy Issues 11: 76-87.

Ahn S. 1997.Economic Analysis of the Potential Impacts of Climate Change on Trout Fishing in the Southern Appalachian Mountains. PhD dissertation. North Carolina State University, Raleigh,NC.

Alig RJ, Adams DM, McCarl BA, Callaway JN. 1997. Assessing effects of mitigation strategies for global climate change with an intertemporal model of the U.S. forest and agriculture sectors.Environmental and Resource Economics 9: 259-274.

Alig RJ, Adams DM, McCarl BA.1998. Impacts of incorporating land exchanges between forestry and agriculture in sector models. Journal of Agricultural and Applied Economics 30: 389-401.

Bailey RO, Kerr-Upal R. 1997.Global climate change: Risks to recreational fisheries and aquatic environments. Kanata,Ontario (Canada): Recreational Fisheries Institute of Canada.

Binkley CS. 1988. A case study of the effects of $\mathrm{CO}_{2}$-induced climatic warming on forest growth and the forest sector, B:E conomic effects on the world's forest sector. In Parry ML, Carter TR, Konijn NT, eds. The Impact of Climatic Variations on Agriculture. Dordrecht (Netherlands): Kluwer.

Birdsey R, Alig R, Adams D. 1999. Mitigation options in the forest sector to reduce emissions or enhance sinks of greenhouse gases. Pages 112-127 in Joyce LA, Birdsey R, eds. The Impact of Climate Change on America's Forests. Portland (OR): USDA Forest Service.General Technical Report PNW-GTR-59. 
Bloomfield J, Hamburg S. 1997. Seasons of Change:Global Warming and New England's White Mountains. New York:Environmental Defense Fund.

Burton DM, McCarl BA, de Sousa NM, Adams DM, Alig RJ, Winnett SM. 1998. Economic dimensions of climate change impacts on southern forests. Pages 777-794 in Fox S. Mickler R, eds.Ecological Studies 128: The Productivity and Sustainability of Southern Forest Ecosystems in a Changing Environment. New York:S pringer-Verlag.

Cordell HK, McDonald BL, Teasley RJ, Bergstrom JC, Martin J, Bason J, Leeworthy VR.1999. Outdoor recreation participation trends. In Cordell HK, ed. Outdoor Recreation in American Life: A National Assessment of Demand and Supply Trends. Champaign (IL): Sagamore Publishing.

Dale VH, et al. 2001. Climate change and forest disturbances. BioScience 51: 723-734 .

Duk M. 1997. Climate Change and Lower Great Lakes Water Levels: The Impacts on Boating in Twelve Mile Bay and Moon Bay. Senior honors essay. University of Waterloo, Department of Geograhy, Waterloo, Ontario, Canada.

Goldewijk KK, van Minnen JG, Kreileman GJJ, Vloedbeld M, Leemans R. 1994. Simulating the carbon flux between the terrestrial environment and the atmosphere. Water, Air, and Soil Pollution 76: 199-230.

Hansen AJ, Neilson RP, Dale VH, Flather CH, Iverson LR, Currie DJ, Shafer S, Cook R, Bartlein PJ. 2001. Global change in forests: Responses of species, communities, and biomes. BioScience 51: 765-779.

Haynes RW, Adams DM, Mills JR. 1995. The 1993 RPA timber assessment update. Fort Collins (CO): USDA Forest Service.General Technical Report RM-GTR-259.

Heath LS, Birdsey RA, Row C, Plantinga AJ. 1996. Carbon pools and fluxes in U.S. forest products. NATO ASI Series I 40: 271-278.

Hoffman C. 1998. Let it snow. Smithsonian 29 (9): 50-58.

[IISD] International Institute for Sustainable Development.1997. The effects of climate change on recreation and tourism on the prairies: A status report. Winnipeg (Manitoba, Canada): International Institute for Sustainable Development.

Irland LC, Cline M. 1998. Role of Northeastern Forests and Wood Products in Carbon Sequestration. Washington (DC): CONEG Policy Research Center. (2 August 2001; www.nrbp.org/publica/htm)

Joyce LA, Birdsey R, eds.2000. The impact of climate change on America's forests: A technical document supporting the 2000 USDA Forest Service RPA Assessment. Fort Collins (CO): U.S. Department of Agriculture, Forest Service, Rocky Mountain Research Station.General Technical Report RMRS-GTR-59.

Joyce LA, Mills JR, Heath LS, McGuire AD, Haynes RD, Birdsey RA.1995. Forest sector impacts from changes in forest productivity under climate change. Journal of Biogeography 22: 703-713.

King GA, Neilson RP. 1992. The transient response of vegetation to climate change: A potential source of $\mathrm{CO}_{2}$ to the atmosphere. Water, Air, and Soil Pollution 94: 365-383.

Loomis J, Crespi J. 1999.Estimated effects of climate change on selected outdoor recreation activities in the United States. In Mendelsohn R, Neumann JE, eds. The Impact of Climate Change on the United States Economy. Cambridge (UK): Cambridge University Press.

McGuire AD, Melillo JM, Joyce LA, Kicklighter DW, Grace AL, Moor B III, Vorosmarty CJ. 1992. Interactions between carbon and nitrogen dynamics in estimating net primary productivity for potential vegetation in North America.Global Biogeochemical Cycles 6: 101-124.

McNulty SG, Aber JD. 2001. United States National Climate Change Assessment on Forest Ecosystems: An introduction. BioScience 51: 720-722.

Melillo JM, McGuire AD, Kicklighter DW, Moore B III, Vorosmarty CJ, Schloss AL. 1993. Global climate change and terrestrial net primary production. Nature 363: 234-240.

Mendelsohn R, Markowski M. 1999. The impact of climate change on outdoor recreation. Pages 231-241 in Mendelsohn R, Neumann JE, eds. The Impact of Climate Change on the United States Economy. Cambridge (UK): Cambridge University Press.

Mendelsohn R, Neumann JE. 1999. The Impact of Climate Change on the United States Economy. Cambridge (UK): Cambridge University Press.
Michaels G, O’Neal K, Humphrey J, Bell K, Camacho R, Funk R. 1995.Ecological impacts from climate change: An economic analysis of freshwater recreational fishing. Washington (DC): US Environmental Protection Agency, Office of Policy, Planning, and Evaluation.EPA 220-R-95-004.

Mills JR, Alig R, Haynes RW, Adams DM. 2000. Modelling climate change impacts on the forest sector. Pages 69-78 in Joyce LA, Birdsey R, eds.2000. The impact of climate change on America's forests: A technical document supporting the 2000 USDA Forest Service RPA Assessment. Fort Collins (CO): U.S. Department of Agriculture, Forest Service, Rocky Mountain Research Station.General Technical Report RMRS-GTR-59.

[NAS] National Academy of Sciences.1992. Policy Implications of Greenhouse Warming. Washington (DC): National Academy Press.

Parks PJ, Hardie EW. 1995. Least-cost forest carbon reserves: Cost-effective subsidies to convert marginal agricultural land to forests. Land Economics 71: 122-136.

Parton WJ, Schimel DS, Cole CV, Ojima DS. 1987. Analysis of factors controlling soil organic matter levels in Great Plains grasslands. Soil Science Society of America Journal 51: 1173-1179.

Parton WJ, et al. 1993. Observation and modeling of biomass and soil organic matter dynamics for the grassland biome worldwide. Global Biogeochemical Cycles 7: 785-809.

Perez-Garcia J, Joyce LA, McGuire AD, Binkley CS. 1997.Economic impact of climatic change on the global forest sector. In Sedjo RA, Sampson RN, Wisniewski J, eds.Economics of Carbon Sequestration in Forestry. Boca Raton (FL): Lewis Publishers.

Plantinga AJ, Birdsey RA.1993. Carbon fluxes resulting from U.S. private timberland management. Climatic Change 23: 37-53.

Portney PR. 1999. Time and money: Discounting's problematic allure. Resources (summer):8-9.

Schaake JC. 1989. Climate change and U.S.water resources: Results from a study by the American Association for the Advancement of Science. Pages 667-672 in Ports MA, ed. Hydraulic Engineering, Proceedings of the 1989 National Conference on Hydraulic Engineering. New York: American Society of Civil Engineers.

Sedjo RA.1989. Forests: A tool to moderate global warming? Environment 31:14-20.

Sedjo RA, Sampson RN, Wisniewski J. 1997.Economics of Carbon Sequestration in Forestry. Boca Raton (FL): Lewis Publishers.

Shaw WD. 1996. Problems with estimating the economic impacts of averting climate change: A look at water resources. Water Resources Research 32:2251-2257.

Skog KE, Nicholson GA. 1998. Carbon cycling through wood products: The role of wood and paper products in carbon sequestration. Forest Products Journal 48: 75-83.

Skog KE, Marcin TC, Heath LS. 1996. Opportunities to reduce carbon emissions and increase storage by wood substitution, recycling, and improved utilization. Pages 209-216 in Sampson RN, Hair D, eds. Forests and Global Change, Vol.2: Forest Management Opportunities. Washington (DC): American Forests.

Smith TM, Shugart HH. 1993. The transient response of terrestrial carbon storage to a perturbed climate. Nature 361: 523-526.

Sohngen B, Alig R. 2000. Mitigation, adaptation, and climate change: Results from recent research on the U.S. forest sector. Environmental Science and Policy 3: 235-248.

Sohngen B, Mendelsohn R. 1998. Valuing the impact of large-scale ecological change in a market: The effect of climate change on U.S. timber. American Economic Review 88: 686-710.

Sohngen R, Sedjo R. 1998. A comparison of timber market models:Static simulation and optimal control approaches. Forest Science 44: 24-36.

Stavins RB. 1999. The costs of carbon sequestration: A revealed-preference approach. American Economic Review 89: 994-1009.

Swanson CS, Loomis JB. 1996. Role of nonmarket economic values in benefit-cost analysis of public forest management. Portland (OR): USDA Forest Service.General Technical Report PNW-GTR-361.

Van Kooten GC. 1995. Climatic-change and Canada boreal forest-Socioeconomic issues and implications for land-use. Canadian Journal of Agricultural Economics 3: 133-148. 
Van Kooten GC, Arthur LM. 1989. Assessing economic benefits of climate change on Canada's boreal forest. Canadian Journal of Forest Research 19:464-470.

VEMAP members.1995. Vegetation/Ecosystem Modeling and Analysis Project: Comparing biogeography and biogeochemsitry models in a continental-scale study of terrestrial ecosystem responses to climate change and $\mathrm{CO}_{2}$ doubling. Global Biogeochemical Cycles 9: 407-437.

Wall G. 1998. Implications of global climate change for tourism and recreation in wetland areas. Climatic Change 40: 371-389.

Watson RT, Noble IR, Bolin B, Ravindranath NH, Verardo DJ, Dokken DJ, eds.2000. Land use, land-use change, and forestry. Cambridge (UK): Cam- bridge University Press (published for the Intergovernmental Panel on Climate Change).

Winjum JK, Brown S, Schlamadinger B. 1998. Forest harvests and wood products: Sources and sinks of atmospheric carbon dioxide. Forest Science 44: 272-284.

Winnett SM. 1998. Potential effects of climate change on U.S. forests: A review. Climate Research 11: 39-49.

Yohe G, Neumann JE, Marshall P. 1999. The economic damage induced by sea level rise in the United States. In Mendelsohn R, Neumann JE, eds. The Impact of Climate Change on the United States Economy. Cambridge (UK): Cambridge University Press.

\section{PU page 641 August Meiji \\ Crystal Clear}

